(C) 2017

Левчук В. І., кандидат технічних наук, Лихвенко С. П., старший викладач

Полтавська державна аграрна академія

\title{
ДОСЛІДЖЕННЯ НАВАНТАЖЕНОСТІ ТА ЕКСПЛУАТАЦЙНИХ РЕЖИМІВ ТРАНСМІСІЇ ТРАКТОРА КЛАСУ 14 КН 3 СИСТЕМОЮ МІЖКОЛІСНОГО АВТОБЛОКУВАННЯ
}

\author{
Рецензент - кандидат технічних наук Г. О. Лапенко
}

\begin{abstract}
Представлені результати експериментального дослідження роботи орного агретату у складі трактора МТ3-80 з навісним плугом ПН-3-35 на супіманому трунті в Білорусї у випадку диференціального та блокованого міжколісного приводу заднього моста у режимі розгону із заглибленням плуга на ходу та з попередньо заглибленим плугом. За допомогою тензометричних датчиків замірялись обертові моменти на валу зчеплення та півосях заднього моста трактора. В результаті аналізу середніх та пікових значень моментів встановлено, що в разі блокованого приводу сумарні моменти на півосях були на 5,931,3\% більші, ніж за диферениіального приводу. Більш навантаженою на усіх режимах випробувань була права піввісь. Максимальні моменти на ній були більші, ніж на лівій на 4,6-20,3\% у разі вимкненої блокіровки і 12,1-32,5\% за ввімкненої.

Виконані розрахунки на міцність півосей трактора за піковими та середніми навантаженнями.

Дослідження навантажень на опори підшипників первинного та вторинного валів коробки передач трактора не виявили значного впливу блокування диференціала на иіі навантаження.
\end{abstract}

Ключові слова: оранка, атретат, трактор, плуг, диференціальний привід, блокований привід, обертаючий момент, півосі, вал зчеплення, режим розгону, заглиблення на ходу, заглиблений плуг, пікові навантаження, коробка передач, вал, опори підщипників.

Постановка проблеми. Універсальнопросапні трактори класу 14-20 кН Мінського тракторного заводу обладнані системою блокування міжколісного диференціала заднього моста 3 гідравлічним приводом, яка дає змогу вмикати блокований привід на тривалий час 3 метою покращання тягово-зчіпних показників трактора та його прохідності. Водночас у разі заблокованого міжколісного приводу відбувається циркуляція потужності між півосями заднього моста внаслідок перерозподілу ведучого моменту, що може призвести до збільшення навантаження на деталі трансмісії та ходової частини трактора i погіршення керованості.
Нами були проведені експериментальні дослідження завантаженості трансмісії трактора МТЗ80 у процесі оранки. Визначались середні та пікові (максимальні) значення обертаючих моментів на півосях та вал зчеплення у процесі розгону орного агрегату на різних передачах із заглибленням плуга на ходу та з попередньо заглибленим плугом. За цими даними планувалось розрахувати на міцність півосі трактора.

3 метою виявлення впливу системи блокування міжколісного диференціала на завантаженість первинного і вторинного валів коробки передач також були проведені експериментальні дослідження.

Аналіз останніх досліджень і публікацій, у яких започатковано розв'язання проблеми. До моменту встановлення на тракторах МТЗ системи міжколісного блокування заднього моста 3 гідравлічним приводом, дослідження впливу блокованого приводу на керованість та тягово-зчіпні якості трактора практично не проводились. У період застосування цієї системи кафедрою «Трактори i автомобілі» Полтавського державного сільськогосподарського інституту був укладений госпрозрахунковий договір з Мінським тракторним заводом. Дослідження за цим договором проводились протягом шести років, відповідно, складались звіти і з'явились публікації. Згідно з [3] були проведені експериментальні дослідження стійкості прямолінійного руху та керованості трактора МТ3-80 в умовах різного зчеплення коліс, коли одна сторона трактора рухалась по слизькій опорній поверхні (лід), а інша по поверхні з високим зчепленням (асфальт) за незначного навантаження на гаку (3,5-3,8 кН). Такий режим роботи трактора характерний для транспортних робіт зимою. Також у [4, 6] досліджувалась керованість, тягові та економічні показники орного агрегату. В джерелах $[1,5]$ представлені результати дослідження завантаженості ведучих півосей та вала муфти зчеплення трактора МТЗ-80 із заблокованим диференціалом на оранці, де, в основному, оцінювалась завантаженість за середніми значеннями моментів на пів- 


\section{TEХНІЧНI НАУКИ}

осях та валу зчеплення та автокореляційними функціями і функціями спектральної щільності процесів змінювання ведучих моментів. Аналізу досліджень завантаженості трансмісії за піковими значеннями моментів на півосях та валу зчеплення приділено менше уваги, тому нашим завданням є більш глибокий аналіз цього питання.

Окрім того, нами не знайдено досліджень впливу блокування диференціала на завантаженість опор підшипників коробки передач.

Мета і завдання досліджень. Метою експериментального дослідження є визначення завантаженості деталей силової передачі трактора MT3-80 з автоматичною системою блокування міжколісного диференціала у процесі оранки у режимі розгону із заглибленням навісного плуга на ходу та $з$ попередньо заглибленим плугом за піковими значеннями обертаючого моменту на півосях та валу зчеплення. Отримані в результаті аналізу досліджень дані дають змогу визначити величину і характер динамічних навантажень на силову передачу трактора, а також максимальні значення моментів на півосях і валу муфти зчеплення, інтенсивність їх наростання у випадку розгону орного агрегату.

Трактор МТ3-80 із навісним плугом ПН-3-35 виконував оранку з на ділянці з супіщаним грунтом. Глибина оранки 28-30 см. Експериментальні дослідження були проведенні згідно із договорами $[1,2]$ з Мінським тракторним заводом на випробувальному полігоні МТЗ у Білорусії.

3 метою виявлення впливу блокування міжколісного диференціала на завантаженість опор підшипників валів коробки передач також були заплановані експериментальні дослідження.

Матеріали і методи досліджень. Дослідження проводились на передачах з другої по шосту. Для отримання необхідних даних трактор був обладнаний тензометричними датчиками, які дали змогу заміряти значення обертаючих моментів на півосях заднього моста, обертаючого моменту на валу зчеплення, частоти обертання колінчастого валу, швидкості руху агрегату, часу досліду, шляху, пройденого за дослід. Параметри досліджень записувались на осцилограми 3 використанням мобільної тензометричної станції на базі автомобіля ГАЗ-53А. Осцилограми були оброблені методами математичного аналізу.

Дослідження проводились за наступною методикою. Орний агрегат рухався прямолінійно по рівній заліковій ділянці поля довжиною 50 метрів. Заїзди проводились на передачах 3 другої по шосту. Тягове навантаження трактора задавалось глибиною оранки у межах 28-30 см. Досліди на кожній передачі проводились за вимкненої i ввімкненої системи автоблокування. Режими руху агрегату були наступні: розгін із заглибленням плуга на ходу (3.н.х) і з попередньо заглибленим плугом, оранка за сталого руху.

Дослідження впливу системи автоблокування міжколісного диференціала на завантаженість опор підшипників валів коробки передач проводились на передачах із першої по шосту в разі роботи трактора на стерні пшениці, зораному полі і асфальтній дорозі, з різними навантаженнями на гаку трактора. Замірялись тензометричними датчиками вертикальна i горизонтальна складові сил, що діють на опори переднього підшипника первинного валу і заднього підшипника вторинного валу.

Результати досліджень. Результати досліджень, отримані після обробки осцилограм та їх аналізу показали, що блокування диференціала у процесі виконання оранки забезпечує збільшення тягового зусилля на гаку за рахунок кращого зчеплення правого колеса, що рухається у борозні. В цілому це призводило до кращого використання зчіпної ваги трактора, зростання сумарного моменту на ведучих колесах i сили тяги, суттєво зменшувалось буксування. У випадку оранки 3 вимкненою блокіровкою перерозподілена між півосями частина ведучого моменту за рахунок сил тертя в диференціалі становила 7-9 \% від сумарного підведеного моменту. В разі роботи із ввімкненою блокіровкою перерозподілена частина моменту зросла до 15,5-33 \% від сумарного підведеного моменту.

Середнє значення коефіцієнта нерівномірності розподілу моменту між півосями на оранці з вимкненою блокіровкою становило 1,08-1,15, а за ввімкненої блокіровки - 1,34-1,70. Значення цього коефіцієнту збільшувалось у разі зменшення глибини оранки і сумарного ведучого моменту.

Завантаженість валів трансмісії визначалися за середніми значеннями обертових моментів на півосях та валу зчеплення, величині їх пікових значень та внутрішній структурі процесів змінювання моментів шляхом оцінки розподілу їх енергї̈ по частотах.

Тензометричними датчиками замірялись момен-

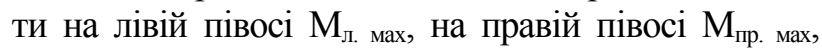

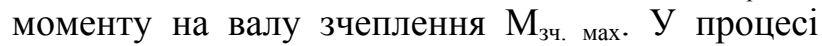
обробки осцилограм визначались максимальні значення моментів. Аналітично визначались сумарний момент на півосях $\sum^{\mathbf{m}}$ та різниця моментів між правою та лівою піввіссю.

Результати досліджень представлені в таблиці. 
Максимальні значення моментів на півосях та валу зчеплення у випадку розгону орного атретату

\begin{tabular}{|c|c|c|c|c|c|c|c|}
\hline $\begin{array}{l}\text { Пере- } \\
\text { дача }\end{array}$ & Блокіровка & $\begin{array}{c}\text { Режим } \\
\text { розгону }\end{array}$ & $\mathrm{M}_{\text {л мах }}, \mathrm{H} \cdot \mathrm{M}$ & $\mathrm{M}_{\text {пр мах }}, \mathrm{H} \cdot \mathrm{M}$ & $\sum_{M}, H \cdot M$ & $\mathrm{H} \cdot \mathrm{M}$ & $\begin{array}{c}M_{34 \text { мaх }}, \\
H \cdot M\end{array}$ \\
\hline \multirow{4}{*}{ II } & \multirow{2}{*}{ вимкнена } & 3.H.X. & 5256,2 & 5858,5 & 11114,7 & 602,3 & 150,1 \\
\hline & & заглибл. & 5924,3 & 6698,3 & 12622,6 & 774,0 & 187,4 \\
\hline & \multirow{2}{*}{ ввімкнена } & 3.H.X. & 6674,7 & 8070,7 & 14745,4 & 1396,0 & 177,6 \\
\hline & & заглибл. & 7592,9 & 9372,5 & 16965,4 & 1779,6 & 189,3 \\
\hline \multirow{4}{*}{ III } & \multirow{2}{*}{ вимкнена } & 3.H.X. & 7341,8 & 7736,2 & 15078,0 & 394,4 & 214,8 \\
\hline & & заглибл. & 7509,6 & 7871,5 & 15381,1 & 361,9 & 287,4 \\
\hline & \multirow{2}{*}{ ввімкнена } & 3.H.X. & 7509,6 & 10448,6 & 17958,2 & 2939,0 & 255,1 \\
\hline & & заглибл. & 8219,8 & 10932,6 & 19152,4 & 2712,8 & 237,4 \\
\hline \multirow{4}{*}{ IV } & \multirow{2}{*}{ вимкнена } & 3.H.X. & 8260,0 & 8738,7 & 16998,7 & 478,7 & 296,3 \\
\hline & & заглибл. & 8447,4 & 8907,5 & 17354,9 & 460,1 & 296,3 \\
\hline & \multirow{2}{*}{ ввімкнена } & 3.H.X. & 8050,1 & 10017,0 & 18067,1 & 1966,9 & 346,3 \\
\hline & & заглибл. & 8200,2 & 11260,9 & 19461,1 & 3060,7 & 310,0 \\
\hline \multirow{4}{*}{ V } & \multirow{2}{*}{ вимкнена } & 3.H.X. & 5506,4 & 5792,8 & 11299,2 & 286,4 & 326,7 \\
\hline & & заглибл. & 6174,4 & 7746,0 & 13920,4 & 1571,6 & 319,8 \\
\hline & \multirow{2}{*}{ ввімкнена } & 3.H.X. & 6091,0 & 8214,9 & 14305,9 & 2123,9 & 323,7 \\
\hline & & заглибл. & 7509,6 & 11130,4 & 18640,0 & 3620,8 & 359,0 \\
\hline \multirow{4}{*}{ VI } & \multirow{2}{*}{ вимкнена } & 3.H.X. & 5006,0 & 5541,7 & 10547,7 & 535,7 & 314,9 \\
\hline & & заглибл. & 6376,5 & 6966,1 & 13342,6 & 589,6 & 377,7 \\
\hline & \multirow{2}{*}{ ввімкнена } & 3.H.X. & 6749,3 & 9764,9 & 16514,2 & 3015,6 & 387,5 \\
\hline & & заглибл. & 9093,9 & 10349,6 & 19443,5 & 1255,7 & 406,1 \\
\hline
\end{tabular}

Аналіз даних таблиці дає змогу зробити висновки, що максимальні значення моментів на півосях за розгону орного агрегату зростали по порядку збільшення номеру передачі від II до IV передачі включно. На V і VI передачах максимуми моментів виявились дещо меншими, що можна пояснити падінням швидкості розгону внаслідок перевантаження двигуна і збільшеним буксуванням трактора. У всіх дослідах навантаження на півосі (моменти $\Sigma \mathrm{M}, \mathrm{M}_{\text {л мах }}, \mathrm{M}_{\text {пр мах) }}$ у разі руху з попередньо заглибленим плугом були більшими порівняно із режимом заглиблення на ходу. Завантаженість півосей також виявилась більшою за розгону із заблокованим диференціалом. Максимальні моменти на правій півосі були завжди більші, ніж на лівій і відрізняються в межах 4,6-20,3\% за вимкненої блокіровки i $12,1-32,5 \%$ - за ввімкненої. Це можна пояснити тим, що праві колеса трактора рухаються у борозні, внаслідок цього на праву піввісь перерозподіляється більша зчіпна вага, відповідно реалізується більший момент, також мають значення різні коефіцієнти зчеплення.

Сумарний момент $\Sigma$ М у випадку блокованого міжколісного приводу за даними таблиці 1 був на 5,9-36,1 \% більшим, ніж за вимкненої блокіровки.

Максимальні моменти на валу зчеплення мають тенденцію до зростання по мірі підвищення передач трактора. Це можна пояснити зростанням сил інерції, які треба переборювати у випадку розгону агрегату на вищих передачах. Особливо чітко це прослідковується в разі розгону із заблокованим диференціалом. Так, момент за ввімкненої блокіровки на II передачі і розгону із заглибленим плугом становить 189,3 H·м, а у цьому ж режимі на VI передачі - 406,1 Н·м і це значення є максимальним для всієї серії випробувань. Воно перевищує значення номінального моменту двигуна $(256,2 \mathrm{H} \cdot \mathrm{m})$ у 1,59 рази. Мінімальне значення моменту на валу зчеплення $(150,1 \mathrm{H} \cdot \mathrm{M})$ зафіксоване на II передачі за вимкненої блокіровки i розгону із заглибленням на ходу.

Максимальне значення сумарного моменту на півосях $\Sigma$ М зафіксоване на IV передачі трактора у режимі розгону із заглибленим плугом і становить $19461,1 \mathrm{H} \cdot$ м, не співпадає із максимальним моментом на валу зчеплення, але перебуває в межах похибки експерименту. Мінімальне значення сумарного моменту становить $10547,7 \mathrm{H} \cdot \mathrm{м}$ і отримане на VI передачі у режимі розгону за вимкненої блокіровки і розгону агрегату в разі заглиблення на ходу. Потрібно брати до уваги, що випробування проводились на реальному агрегаті в польових умовах, а не на математичній моделі. 


\section{TEХНІЧНІ НАУКИ}

Різниця моментів між півосями $\Delta$ М впливає на керованість трактора, оскільки вона створює сили, які намагаються повернути трактор вліво i для переборення дії цих сил необхідно тримати кермо трактора повернутим вправо на певний кут. За результатами досліджень [6] цей кут досягає значення $10^{0}$ повороту керованих коліс трактора.

Як уже було відзначено у $[1,5]$, під час врахування середніх значень моментів на півосях за сталого руху орного агрегату, загальний запас їх міцності становить 1,25-1,75, що на $15 \%$ нижче даних МТЗ. Під час врахування пікових значень моментів у режимі розгону агрегату із заблокованим диференціалом запас міцності для найнебезпечніших перерізів становить 1,1-1,41.

Розрахункова перевірка напружень у різних перерізах більш навантаженої (правої) півосі у випадку заблокованого диференціала, проведена за методикою МТ3 показала, що із врахуванням пікових навантажень у випадку розгону орного агрегату із заглибленим плугом, запас міцності по обертаючому моменту у зоні галтелі (16,5 мм вправо від зовнішньої опори) становив 1,58, а в зоні шпоночної канавки (83 мм вправо від зовнішньої опори - 1,02. Загальний запас міцності в тих же перерізах півосі за ширини колії задніх коліс трактора 1400 мм становив, відповідно, 1,41 i 1,00, що на 60-65 \% нижче запасу міцності за розрахунками Мінського тракторного заводу.

Проведені також дослідження навантаження на опори підшипників коробки передач. Замірялись вертикальна і горизонтальна складові сил, що діють на опори переднього підшипника первинного валу, вертикальна складова навантаження на опору заднього підшипника вторинного валу і результуюча сила із вимкненою та ввімкненою блокіровкою на стерні пшениці, зораному полі та асфальтній дорозі з різними навантаженнями на гаку трактора на передачах 3 першої по п’яту.

Отримані результати експериментальних досліджень [6] дають змогу зробити висновки, що як складові, так і результуючі навантажень на підшипники значно нижчі допустимих за норми

\section{БІБЛІОГРАФІЯ}

1. Исследование управляемости и нагруженности силовой передачи трактора кл. 1,4 тс с автоблокирующимся дифференциалом: Отчет о НИР / Полтавск. сельхозинститут. - МТЗ. №617. - Полтава, 1974. - 32 с.

2. Исследование эксплуатационных режимов трансмисии трактора МТ3-80 с автоблокирующимся дифференциалом: Отчет о НИР. - їх роботоздатності. Суттєвої різниці у значеннях навантажень на підшипники коробки передач у випадку роботи трактора із заблокованим і розблокованим диференціалом не виявлено.

\section{Висновки:}

1. На оранці супіщаного грунту, типового для умов Білорусіі, робота трактора МТ3-80 із заблокованим диференціалом призводила до перерозподілу ведучого моменту між півосями в 1,34-1,79 рази і до збільшення сумарного ведучого моменту до 4-46 \% порівняно 3 оранкою в тих же умовах 3 вимкненою блокіровкою. В середньому, за результатами усіх дослідів, зростання сумарного моменту на ведучих колесах у випадку блокованого диференціала становило $16 \%$

2. Максимальні (пікові) навантаження на правій півосі мали місце при розгоні агрегату iз заблокованим диференціалом і досягали значення $11269,9 \mathrm{H} \cdot$ м (за 8200,2Н·м на лівій півосі). В середньому пікові значення моментів на правій півосі в разі розгону із заблокованим диференціалом на 15-70 \% перевищували навантаження на тій же півосі у випадку розблокованого диференціала. Максимальні навантаження на валу зчеплення досягали значення 387,5-406,1 Н·м у разі розгону на VI передачі із блокованим 141 міжколісним приводом. Сумарний момент $\Sigma \mathrm{M} \mathrm{у}$ випадку блокованого 141 міжколісного приводу був на 5,9-36,1 \% більшим, ніж за вимкненої блокіровки.

3. Загальний розрахунковий запас міцності із врахуванням пікових значень моментів більш навантаженої (правої) півосі для найбільш небезпечних перерізів становить 1-1,41.

4. Дослідження впливу блокування диференціала на завантаженість підшипників первинного i вторинного валів коробки передач показали несуттєвий вплив блокування на значення горизонтальної, вертикальної і результуючої сили.

У наступних дослідженнях необхідно приділити більше уваги впливу системи блокування міжколісного диференціала на витрату палива під час виконання трактором різних операцій.

№417. - Полтава : Полтавск. сельхозинститут MT3, 1972. - C. 28-32.

3. Лихвенко С. П., Харак Р. М. Експериментальне дослідження стійкості прямолінійного руху трактора в умовах різного зчеплення ведучих коліс / С. П. Лихвенко, Р. М. Харак // Вісник Полтавської державної аграрної академії. - 2012. - №1. - C. 178-180. 


\section{TEХНІЧНI НАУКИ}

4. Лихвенко С. П., Харак Р. М. Аналіз роботи орного агрегату 3 трактором МТЗ-80 із диференціальним і блокованим міжколісним приводом / С. П. Лихвенко, Р. М. Харак // Вісник Полтавської державної аграрної академії. - 2013. - №3. C. $171-174$.

5. Скоробогатый Г. Ф. Исследование нагруженности ведущих полуосей трактора МТ3-80 с автоблокирующимся дифференциалом на пахоте / Г. Ф. Скоробогатый, С. П. Лыхвенко, А. И. Пи- липенко. - В сб. «Совершенствование конструкций, улучшение ремонта и эксплуатации сельскохозяйственных машин» // Тр. Харьк. с-х. инта им. В. В. Докучаева. - Т. 215. - Х., 1976. C. 57-62.

6. Харак Р. М. Експериментальне дослідження керованості та тягових показників трактора класу 14 кН на оранці / Р. М. Харак, В. І. Левчук, С. П. Лихвенко // Вісник Полтавської державної аграрної академії. - 2015. - №3. - С. 144-149. 